\title{
Preventing health water related risks in growing megacities: the Southern part of Mexico City
}

\author{
R. Rodriguez-Castillo \& M. A. Armienta-Hernandez \\ Geophysics Institute, \\ Universidad Nacional Autonoma de Mexico, Mexico
}

\begin{abstract}
Megacities in developing countries are growing without environmental controls. New poor neighborhoods are located in formal urban area surroundings. In Mexico City urbanization is going to the volcanic hillsides of the Sierra Chichinautzin range. The volcanic environment and rocks restricts the sewage line construction. Some people conduct wastewater to natural cavities.

Some wells located in piedmont contain organic matter and consequently nitrogen compounds. The geologic environment (lacustrine sediments rich in organic matter, volcanic rocks) propitiates the presence of sulphur compounds.

A groundwater monitoring was carried out in the Southern part of Mexico City. Chemical analyses included trace elements, organic compounds (volatiles) and water stable isotopes. Nitrates, arsenic, and chlorination transformation products were detected. However, very low concentrations of volatiles and arsenic were determined. The detection of wells with quality of water problems and potential contamination sources around them is helping to improve water management. Treatment plants in contaminated wells are another proposed solution, due to the limitations in water availability.
\end{abstract}

Keywords: Basin of Mexico, health risks, sanitation.

\section{Introduction}

The Mexico City Metropolitan Area in the Basin of Mexico, MCMA, encompasses the Federal District where Mexico City and the adjacent municipalities of the state of Mexico are located (Fig 1). Mexico City is divided into 16 Delegations. The population is estimated at more than 20 million people. 
Water supply is complicated by the fast growing of new irregular settlements and by the wide variation of population density, ranging from 130 up to $18,000 \mathrm{ind} / \mathrm{km}^{2}$ (Tortajada and Castelan [9]). The Basin of Mexico is a closed basin of $9,600 \mathrm{~km}^{2}$. In late 2007, the MCMA occupied $4900 \mathrm{~km}^{2}$. Water supply is based in its own sources, mainly groundwater. The MCMA requires more than $70 \mathrm{~m}^{3} / \mathrm{s}$ of water to satisfy the urban, agricultural and industrial needs.

Precipitation in the Basin of Mexico varies from 600 to $1200 \mathrm{~mm}$ in the highlands. The abstraction of the local aquifer system provides about $50 \mathrm{~m}^{3} / \mathrm{s}$. Recharge has been estimated at $20 \mathrm{~m}^{3} / \mathrm{s}$ (Birkle et al. [3]). The Basin presents a water deficit of $30 \mathrm{~m}^{3} / \mathrm{s}$. To complete water requirements, the MCMA imports $15 \mathrm{~m}^{3} / \mathrm{s}$ from external sources, mainly from the Cutzamala system (Herrera and Dumars [4]).

Although in general water quality is acceptable, Mexico is the second international market of purified water, representing sales of more than $18 \mathrm{M}$ $1 /$ day. Poor people are taking water directly from urban pipelines; in some cases they use boiled water. All distributed water is chlorinated. In general, Mexican people do not use urban water from pipelines because of a general perception of bad quality. The consumption of the so-called purified water reduces the exposure to water with not so good quality, minimizing health risks.

The Water System of Mexico City (Sistema de Agua de la Ciudad de Mexico), SACM, periodically carries out chemical analyses of water samples from urban wells. The SACM is only responsible for 541 urban wells. The Southern System is formed by 5 subsystems, operating 254 wells.

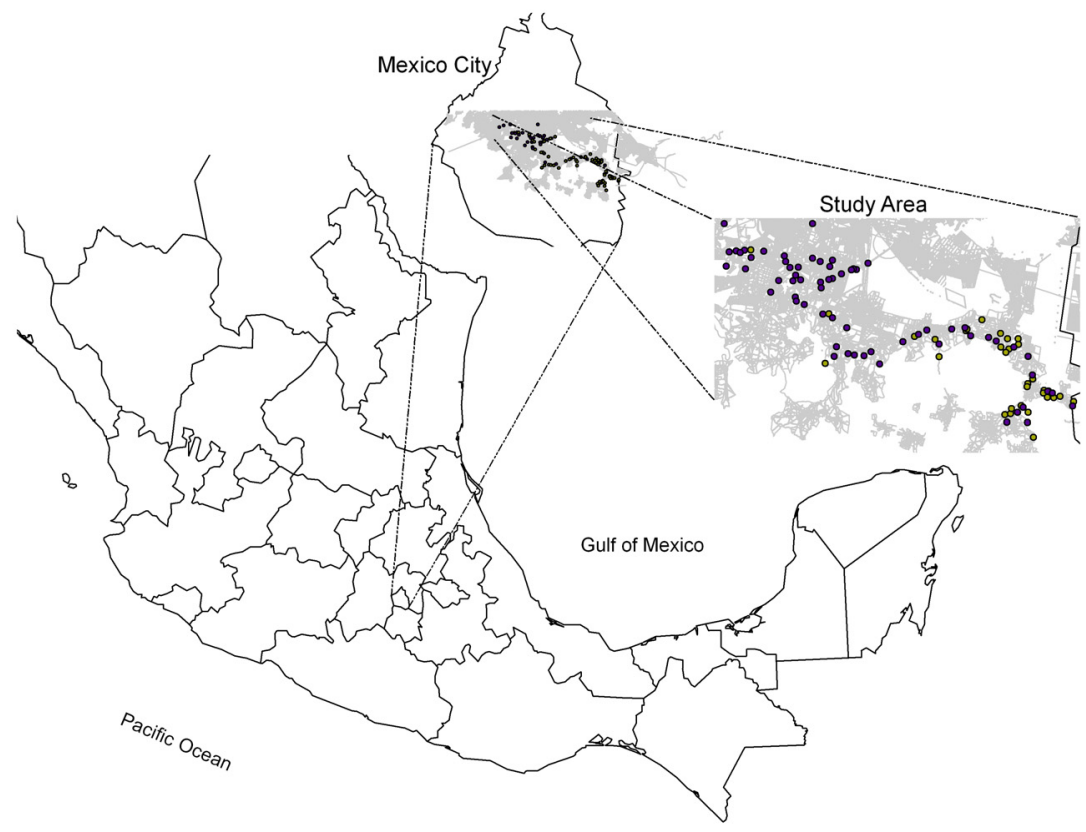

Figure 1: $\quad$ Southern part of the Basin of Mexico. 
The urban area of the southern part of Mexico City is growing to volcanic hillsides of the Sierra Chichinautzin range. The range is formed by very permeable volcanic rocks.

Some new communities established in hillsides, piedmont and transition zone in this part of the Basin, have no sewage systems due to the abrupt topography and to the volcanic environment constituted by hard rocks. This is one of the rural areas of Mexico City.

\section{Geological and hydrogeological framework}

The Basin of Mexico is surrounded by volcanic ranges. The southern part is occupied by the Sierra de Chichinautzin range. This range is formed mainly of quaternary basalts and is the most important recharge area for the Mexico City aquifer. In the plain, superficial lacustrine clay deposits from the former and existing lakes bottoms form a layer of very low permeability which, in some way, protects the aquifer system from superficial contaminants. Alluvial sediments interstratified with Pleistocene and recent basalt deposits underlie the lacustrine clays. These permeable layers comprise the upper portion of the principal water supply aquifer overlying stratified volcanic deposits. Pliocene lacustrine clay deposits are found under the aquifer units. Clay layers conform an aquitard where subsidence is occurring.

In the Basin three hydrologic zones were defined; the lacustrine zone, the piedmont or transition zone, and the mountain zone. The study area comprises part of the mountain and transition zones, although some wells reach the lacustrine sediments. The piedmont region is located between the former lake beds and the mountains. The piedmont is defined by very permeable fractured basalts.

To the south the aquifer is not confined whereas to the north it is confined by the lacustrine clays. In the area, a sequence of Quaternary volcanic rocks constitutes the aquifer, with basaltic andesite predominating over basalts and andesites. The water table is located at a depth of 70-80 m in wells placed in the upper part of hillsides. The preferential groundwater flow direction is N-S

\section{Methodology}

A previous selection of wells was made based on existing hydrochemical information. 120 wells were chosen from the 248 active wells at that moment. A first monitoring was carried out during June 2008; a second one was done early April 2009. 120 samples were taken from 86 different wells. Some wells were sampled twice according to the first results (to confirm results or to check for exits variation in some parameters). The information was handled in a Geographical Information System. Sampling was done according to international and national standards (EPA [10]; SSA [7]). New prewashed bottles were used. Sulfuric acid was added to preserve the samples for nitrates, $\mathrm{NO}_{3}$. Samples were transported to the Geophysics Institute Analytical Lab the same day. Six samples were taken, one of them for nitrates. Nitrates were determined by 


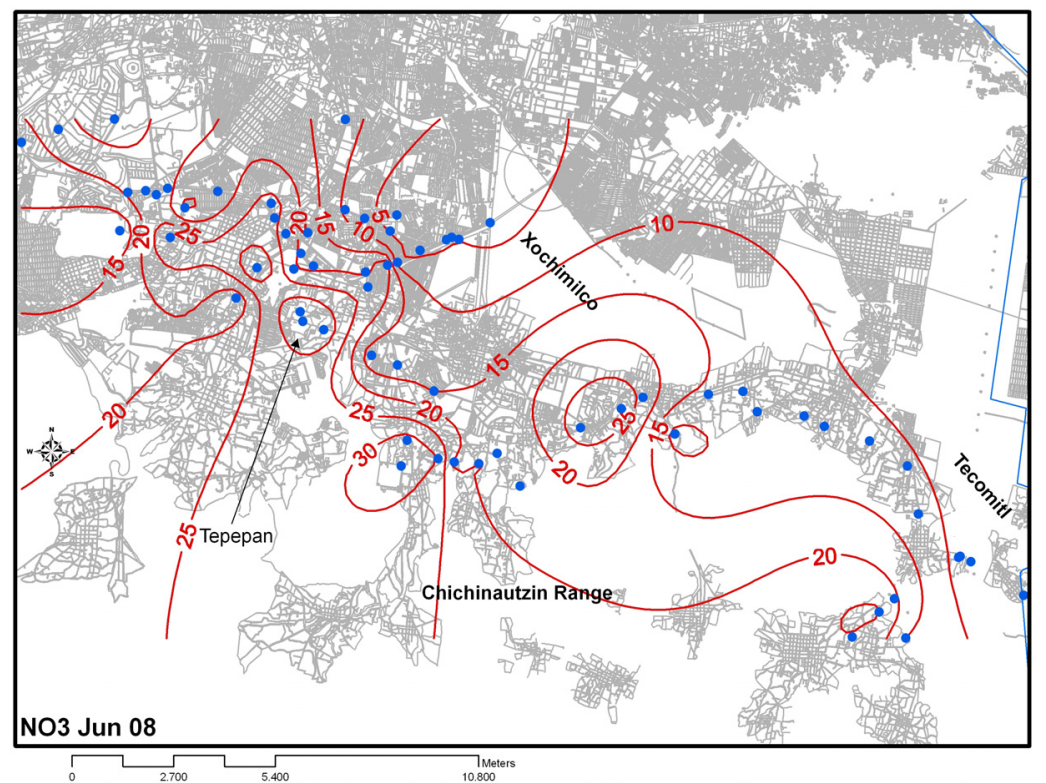

Figure 2: $\quad$ Groundwater nitrates distribution, June 08.

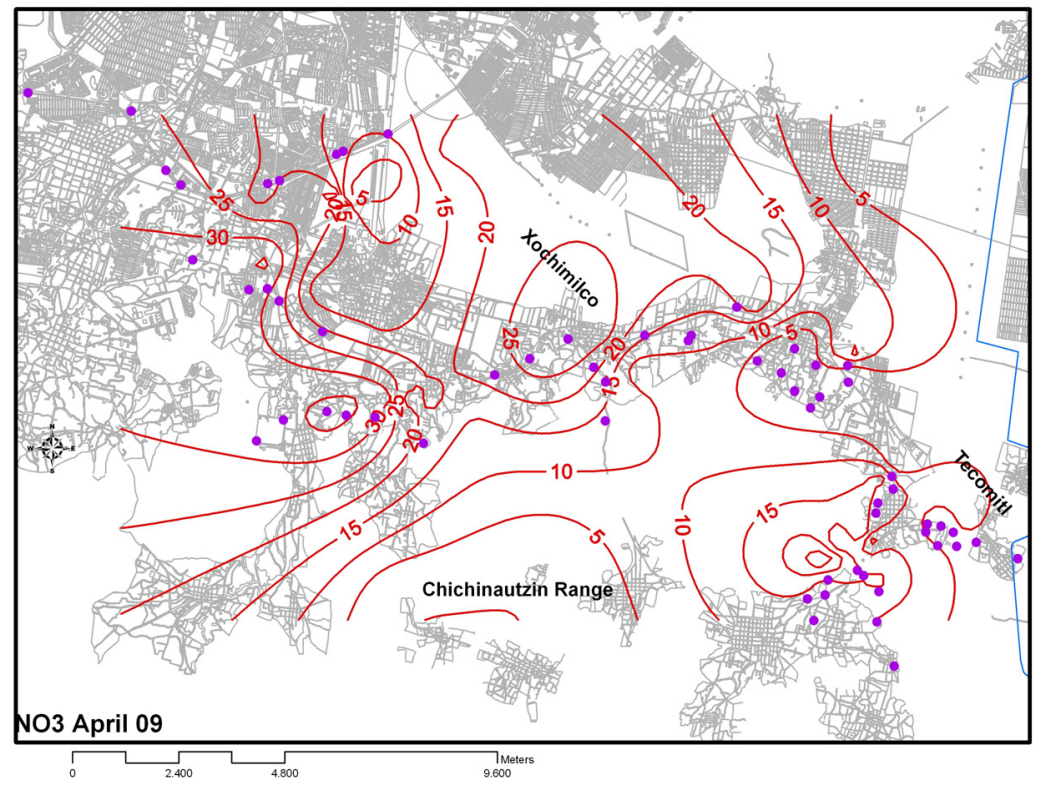

Figure 3: $\quad$ Groundwater nitrates distribution, April 09. 


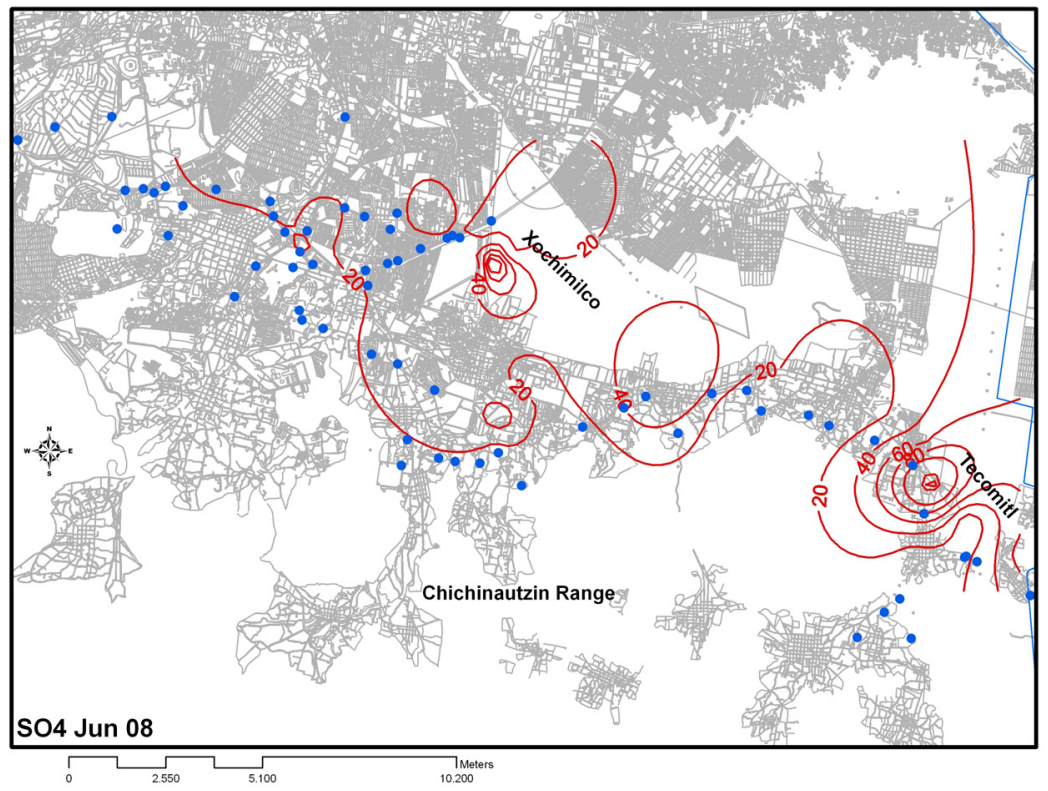

Figure 4: Groundwater sulfate concentrations, June 2008.

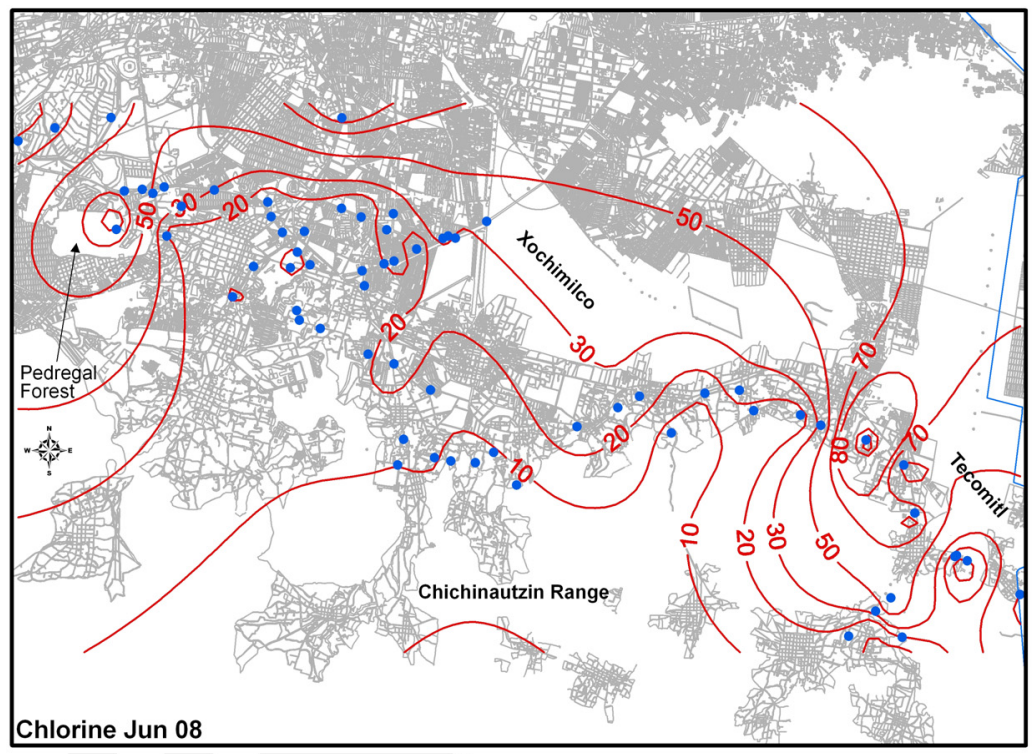

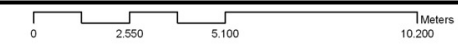

Figure 5: $\quad$ Chloride distribution, June 2008. 
measurement of UV absorption at $220 \mathrm{~nm}$, and $275 \mathrm{~nm}$ to correct for organic matter content, with a uv-visible spectrophotometer HP 8452A.

\section{Results}

Nitrates over a detection limit were detected in $95 \%$ of the wells. $\mathrm{NO}_{3}$ concentrations do not exceed the national standard for drinking water for $\mathrm{NO}_{3}-\mathrm{N}$ of $10 \mathrm{mg} / \mathrm{L}$. Nitrate concentrations are greater than contents found in wells located to the center and north of the Basin. Huizar and Coll reported $\mathrm{NO}_{3}$ values ranging between 0.1 to $2.3 \mathrm{mg} / \mathrm{L}$.

Detected sulfates concentrations did not exceed the WHO [11] recommendations, $250 \mathrm{mg} / \mathrm{L}$. In Xochimilco and Tecomitl areas contents of up $100 \mathrm{mg} / \mathrm{L}$ were found. Samples with these values showed a yellow color and smell. To the north of the Basin contents lower than $40 \mathrm{mg} / \mathrm{L}$ are reported (Huizar et al. [5]).

Pedregal Forest and Tecomitl wells have higher chloride concentrations, up to $80 \mathrm{mg} / \mathrm{L}$. These concentrations are lower than the WHO recommendations, of $250 \mathrm{mg} / \mathrm{L}$. Chloride background found in a similar basin in the Mexican Highlands is $20 \mathrm{mg} / \mathrm{L}$ (Rodriguez et al. [8]).

Wells located to the transition zone show higher concentrations of nitrates, sulfates, chloride and electrical conductivity than wells placed in the hillsides.

Arsenic, As; was detected in some wells located to the west part of the study area. Arsenic concentrations are much lower than the national standards for drinking water, $0.025 \mathrm{mg} / \mathrm{L}$. Its presence is associated with the volcanic environment.

\section{Discussion}

The fast growing of megacities like Mexico City complicates water supply and sanitation. Required volumes of potable water increase every year. Limited availability and local problems of water quality alteration led water authorities to have strict control of water quality.

The southern part of the Basin of Mexico is one of the MCMA areas of faster urban growing. Green areas, even ecological reserves, are being reduced. The Sierra de Chichinautzin hillsides do not offer the best conditions for urbanization. Topography is very abrupt, the rock hardness makes for difficult sewage pipeline installation. Fractures and natural cavities are being used as easy and cheap septic systems. There are no springs and the water table depth does not permit dug well drilling.

The fast infiltration of rain water and water coming from sewages can explain the presence of nitrates in wells in the transition zone. Chloride and relatively high electrical conductivities of water, in the areas with higher $\mathrm{NO}_{3}$ concentrations, support the hypothesis of water quality alteration by anthropogenic causes. However, a natural contribution is not discarded.

Some wells located in Tecomitl contain nitrate and sulfate in relatively high concentrations. They were drilled in the transition zone reaching lacustrine 
sediments. These layers contain organic matter in decomposition, generating nitrates. This difference in the hydrochemical behavior is supported by the in situ perception of the characteristic smell and colour associated with sulfur compounds. Wells located to the west, out of the influence area of the lacustrine medium do not have this peculiarity.

The presence of nitrates in some wells can be associated with wastewater infiltrations from latrines, leakages from sewage and from organic matter decomposition. Infiltrated rain water incorporates leakages from the rustic septic systems to the aquifer.

Nitrates can be an indicator of bacterial contamination. Mazari-Kriart et al. [6] found fecal pollution in wells located in the southern part of the Basin and warned of the health risk when water is distributed and used without adequate disinfection.

The volcanic environment can explain the presence of arsenic. The As detected contents do not exceed the national standard for drinking water, $0.025 \mathrm{mg} / \mathrm{L}$.

The SACM installed treatment plants in some wells, 5 years ago. The installation of similar plants in wells with $\mathrm{NO}_{3}$ and $\mathrm{SO}_{4}$ can be a solution to improve the quality of supplied water.

Water mixing is the most popular action for improving the water quality. Polluted water is conducted to aqueducts that receive clean water from other wells, reducing the content of risky components.

Sampling did not include microbiological analyses, but results suggest that microbiological contamination can occur in areas with high $\mathrm{NO}_{3}$ content. Bacteriological analyses must be undertaken in wells located in the transition zone. It is unlikely that wells drilled in the upper part of hillsides are contaminated. Although shallow basalts are very permeable, their depths are very high, limiting the bacterial existence.

Water chlorination reduces health risk related to water ingestion, but many people took water directly from wells supposing a good quality. A campaign insisting in water consumption from pipelines can reduce the exposure.

People are very sensitive to information regarding water scarcity and health effects. Informative campaigns must be undertaken by interdisciplinary groups.

\section{Acknowledgements}

The authors thank the financial support offered by the Science and Technology Institute ICyT (Instituto de Ciencia y Tecnologia) of Mexico City Government. Chemical analyses were performed by Aguayo A., Cisneros N. and Cruz O.

\section{References}

[1] Armienta A. and Rodriguez R., Monitoreo de agua subterránea del Sur de la Cuenca de Mexico, Technical Report, ICyT, GDF, IGF-UNAM, 2009 
[2] Carrera J. and Gaskin S., The Basin of Mexico aquifer system: regional groundwater level dynamics and database development, Hydrogeology Journal, Volume 15, Number 8, 1577-1590 pp, 2007.

[3] Birkle, P., Torres Rodríguez V. and González Partida, E., The water balance for the Basin of the Valley of Mexico and implications for future water consumption. Hydrogeology Journal, Volume 6, Number 4, 1998.

[4] Herrera I. and Dumars Ch., (Compiladores), El agua y la Cd. de México. Consejo Nal. de Investigación, Acad. Investigación Científica, National Research Council, Mexico, 165 pp. 1995

[5] Huizar R., Mendez T. and Madrid-Rios R., Hidrogeoquimica del agua subterránea de la Sub Cuenca de Apan-Tochac, Hidalgo México. Rev. Mex. De Ciencias Geológicas, Vol 16 num 1, 89-96 pp, 1999.

[6] Mazari-Kriart, M., Torres-Beristain, B., Velázquez, E., Calva J. J. and Pillai, S. D., Bacterial and viral indicators of fecal pollution in Mexico City's Southern aquifer, Journal of Environmental Science and Health, Part A, Volume 34, Issue 9, 1715 - 1735 pp, 1999

[7] Norma Oficial Mexicana NOM-0140-SSA1-1993, Procedimientos sanitarios para el muestreo de agua para uso y consumo humano en sistemas de abastecimiento de agua públicos y privados. Secretaria de salubridad y asistencia, Mexico, 1993

[8] Rodriguez R., Armienta A., Morales P, Silva T and Hernández H., 2006; Evaluación de Vulnerabilidad Acuífera del valle de Irapuato Gto. JAPAMI, CONCyTEG, IGF UNAM. Reporte Técnico il. 90 pp.

[9] Tortajada C. and Castelan E., Water Management for a Megacity: Mexico City Metropolitan Area. AMBIO: A Journal of the Human Environment, vol 32 issu2 2, 124-129 pp, 2003

[10] USEPA, Drinking water regulations and health advisories. Office of Water, US EPA, 1996

[11] World Health Organization, Guidelines for drinking Water Quality. Third Edition, Vol. 1, Geneva, 2004 